Dr MILAN BALABAN, naučni saradnik

Univerzitet Tomaša Bate u Zlinu, Informacioni centar Bata

Zlin, Češka Republika

balaban@utb.cz

Dr DALIBOR SAVIĆ, docent

Univerzitet u Banjoj Luci, Fakultet političkih nauka

Banja Luka, Republika Srpska, Bosna i Hercegovina

dalibor.savic@fpn.unibl.org

Mr JAN HERMAN, istraživač-saradnik

Univerzitet Tomaša Bate u Zlinu, Informacioni centar Bata

Zlin, Češka Republika

herman@utb.cz

originalan naučni rad / original scientific paper

primljeno / received: 31. 3. 2020.

prihvaćeno / accepted: 20. 11. 2020.

https://doi.org/10.29362/ist20veka.2021.1.bal.53-76

\title{
PROTESTI PROTIV FIRME BATA: PRILOG PROUČAVANJU ANTIINDUSTRIJSKIH PROCESA U KRALJEVINI SRBA, HRVATA I SLOVENACA/JUGOSLAVIJI
}

APSTRAKT: U članku se predstavljaju antiindustrijski procesi u Kraljevini Srba, Hrvata i Slovenaca (Kraljevina SHS), kasnije Kraljevini Jugoslaviji. U tom kontekstu posebna pažnja je posvećena protestima protiv firme Bata, koja je svojim dolaskom na tržište Kraljevine SHS potisnula domaću industrijsku i zanatlijsku proizvodnju u kožarskoj industriji, to jest produbila nepovoljan socijalni položaj stanovništva egzistencijalno zavisnog od domaće proizvodnje obuće. U radu se razmatraju i regulatorne mjere koje su preduzimale vlasti Kraljevine SHS/Jugoslavije u nastojanju da olakšaju položaj domaćih zanatlija usljed tržišne ekspanzije firme Bata. Istraživanje je zasnovano na analizi neobjavljene arhivske građe iz arhiva u Češkoj Republici, Srbiji i Hrvatskoj, odnosno analizi relevantne naučne literature posvećene navedenoj problematici. Rezultati istraživanja ukazuju da je i pored organizovanog otpora zanatlija $i$ regulatornih mjera firma Bata do kraja 1930-ih uspjela da postigne praktični monopol u proizvodnji i prodaji obuće na tržištu Kraljevine Jugoslavije.

KLJUČNE RIJEČI: Firma Bata, Jugoslavija, Čehoslovačka, međuratno razdoblje, antiindustrijski protesti, obućarska industrija, zanatlije 


\section{Uvod}

Industrijski razvoj Kraljevine SHS, od 1929. Kraljevine Jugoslavije, bio je obilježen mnogobrojnim poteškoćama i protivrječnostima. Kao osnovne razloge za usporen rast jugoslovenske industrije u međuratnom periodu većina istraživača navodi niz strukturalnih problema (periferan položaj u okviru globalne ekonomije, visoke kamate pri uzimanju stranih kredita za kupovinu mašina, nekvalifikovana radna snaga, niski proizvodni kapaciteti i zastarjela tehnologija, neracionalno vođenje preduzeća itd.) i/ili loših ekonomskih politika (izostanak odgovarajućih planskih mjera usmjerenih ka podsticanju industrijskog razvoja, državni intervencionizam $u$ korist poljoprivrednog sektora, neadekvatne i neefikasne mjere carinske i poreske politike itd.), tj. specifične društvene procese sa izraženim antiindustrijskim obilježjima. ${ }^{1}$ Između ostalog, neki od antiindustrijskih procesa u Kraljevini SHS/Jugoslaviji počivali su i na organizovanom otporu pojedinih udruženja zanatlija. Za adekvatno razumijevanje prethodne tvrdnje bitno je istaći da zanatlije nisu nužno ,gubitnici industrijalizacije“, 2 već da je njihov socijalni status u izmijenjenim društvenim okolnostima uslovljen dostignutim stepenom industrijskog razvoja i vrstom zanata kojim se bave. Pišući o stanju u (do)tadašnjoj jugoslovenskoj privredi Stevan Kukoleča ističe da ,industrija potiskuje izvjesne vrste zanata i razvija se na njihovu štetu, dok se sa drugima dopunjava“, odnosno da su gubitnici industrijalizacije tekstilni, kožarski i većina zanata povezanih sa preradom metala, a dobitnici elektrotehnički, hemijski, grafički i zanati povezani sa preradom papira. ${ }^{3} \mathrm{U}$ kontekstu navedenog, fokusiraćemo se na predstavljanje društveno-istorijskih dešavanja koja su obilježila organizovani otpor/proteste jugoslovenskih obućara (i drugih kožarskih radnika) protiv ekspanzije firme Bata (Bat’a) na domaćem tržištu.

Tema opšteg razvoja firme Bata u Jugoslaviji je već privukla pažnju kako jugoslovenske i postjugoslovenske, tako i češke istoriografije. ${ }^{4}$ Međutim, pitanje protesta protiv ekspanzije firme Bata na jugoslovenskom tržištu u okviru prethodno navedenih istoriografskih tradicija još uvijek nije adekvatno istraženo. Smatramo da će ovaj rad predstavljati značajan doprinos u razumijevanju

\footnotetext{
${ }^{1}$ Npr. Sergije Dimitrijević, Karakteristike industrije i rudarstva bivše Jugoslavije (Beograd: Biblioteka Društva ekonomista Srbije, 1949); Smiljana Đurović, Državna intervencija u industriji Jugoslavije (1918-1941) (Beograd: Institut za savremenu istoriju, 1986); Mari-Žanin Čalić, Socijalna istorija Srbije 1815-1941 (Beograd: Clio, 2004).

${ }^{2}$ Videti u: Daron Asemoglu i Džejms A. Robinson, Zašto narodi propadaju: Poreklo moći, prosperiteta i siromaštva (Beograd: Clio, 2014), 98-99.

3 Stevan M. Kukoleča, Industrija Jugoslavije 1918-1938 (Beograd: Balkanska štampa a. d., 1941), 61-62.

${ }^{4}$ Između ostalih djela koja se bave temom firme Bata u Jugoslaviji izdvajamo: Kemal Hrelja i Martin Kaminski, Borovo. Jugoslovenski kombinat gume i obuće (Slavonski Brod: Historijski institut Slavonije, 1971); Martin Jemelka i Ondřej Ševeček, Tovární města Batova koncernu: Evropská kapitola globální expanze (Praha: Academia, 2016); Dražen Živić i dr., Bata-Borovo (1931. 2016.). Povijesno naslijeđe i perspektive (Zagreb - Vukovar: Institut društvenih znanosti Ivo Pilar, 2019); Milan Balaban, Podnikáni firmy Bata v Jugoslávii (Zlín: Univerzita Tomáše Bati, 2018).
} 
pomenute problematike, ali i šireg trenda anti-Batinih protesta koji su se tokom međuratnog perioda širili od zapada ka istoku Evrope. Zbog boljeg razumijevanja pomenutih društveno-istorijskih dešavanja, prije nego što se posvetimo samom pitanju anti-Bata protesta u Kraljevini SHS/Jugoslaviji, prvo ćemo predstaviti kratke preglede istorije firma Bata u globalnim i jugoslovenskim okvirima do početka četrdesetih godina 20 . vijeka.

\section{Istorija firme Bata u globalnim okvirima}

Početak istorije firme Bata je vezan za 21. septembar 1894. kada su Ana (Anna), Antonjin (Antonín) i Tomaš Bata (Tomáš Bat’a) ${ }^{5}$ osnovali obućarsku firmu u Zlinu (Zlínu), tadašnja Austro-Ugarska, danas Češka Republika. Početkom 20. vijeka firma se razvijala veoma uspješno i to prvenstveno zahvaljujući tehnološkim inovacijama i specifičnoj organizaciji rada. Uvođenje novog tipa obuće, lakih platnenih cipela, tzv. batjovki (bat'ovky), takođe je doprinijelo naglom uspjehu firme. ${ }^{6}$ Ipak, kraj Prvog svjetskog rata, to jest nestajanje Austro-Ugarske sa njenim velikim unutrašnjim tržištem, firmu je suočio sa nizom problema vezanih za plasman njenih proizvoda. Krizu u poslovanju rukovodstvo fabrike je savladalo zahvaljujući kako dobrim menadžerskim potezima - poput sniženja cijena proizvoda na polovinu, ${ }^{7}$ što je donijelo prijeko potrebnu injekciju gotovog novca u koncern, tako i daljom racionalizacijom proizvodnje po uzoru na američke modele (tejlorizam, fordizam). Uvedena je i nova organizacija proizvodnje zasnovana na samoupravi radionica i učešću radnika u profitu preduzeća, što je bilo u skladu sa proklamovanom politikom firme o visokim radničkim platama, niskim cijenama za kupce i razumnim profitom za preduzetnika. ${ }^{8} \mathrm{Uz}$ to, ponovnoj tržišnoj ekspanziji firme u velikoj mjeri je doprinijeo i povoljan razvoj konjunkture nakon ranih 1920-ih godina.

\footnotetext{
5 Tomaš Bata (1876-1932), čehoslovački preduzetnik poznat i kao „Kralj obuće“, bio je osnivač firme koja je tokom 20. vijeka dostigla globalan uspjeh. Od 1923. do 1932. obavljao je dužnost gradonačelnika Zlina. Bata je u svojim preduzećima razvijao izvorne metode proizvodnje i upravljanja, kao i motivacije zaposlenih i poslovnog obrazovanja. Kao gradonačelnik, razvijao je grad Zlin pod konceptom „Fabrike u vrtovima“ sa originalnom funkcionalističkom arhitekturom. „Batin“ model fabričkih i stambenih četvrti je primijenjen i na druga mjesta u Čehoslovačkoj, Europi i svijetu, gdje su izgrađeni njeni fabrički kompleksi. Tomaš Bata je poginuo 12. jula 1932. u avionskoj nesreći u Otrokovicama (tadašnja Čehoslovačka). Pod njegovim vođenjem firma je izrasla u globalno preduzeće koje je funkcionisalo na četiri kontinenta, zapošljavalo preko 31.000 ljudi, prodavalo svoju robu u 2.500 sopstvenih prodavnica i proširilo djelovanje na 35 različitih područja industrije, trgovine, saobraćaja, finansija i usluga.

${ }^{6}$ Moravský zemský archiv v Brně, Státní okresní archiv Zlín (dalje SOkA Zlín), fond (dalje f.) Bat'a a. s., II/3, k. 1155 , inv. č. 33.

${ }^{7}$ František X. Hodáč, Tomáš Bata: Život a práce hospodářského buditele (Zlín: Univerzita Tomáše Bati, 2015), 428-432.

${ }^{8}$ Zdeněk Pokluda, Cllověk a práce: $z$ ekonomických principů a vizi Tomáše Bati $=$ Man and Work: The Vision and Principles of Economics of Tomas Bata (Zlín: Nadace Tomáše Bati, 2015), 20-22.
} 
Uspješnu poslovnu ekspanziju firme u inostranstvu ${ }^{9}$ usporile su posljedice Velike ekonomske krize koja je izbila u oktobru 1929. godine. Tokom nje su pojedine zemlje počele uvoditi protektivne carine zarad zaštite domaće proizvodnje, a u okviru tih mjera kreirale su i različite mehanizme koji su imali za cilj smanjenje prodaje Batine obuće. To je prinudilo T. Batu, kao i njegove nasljednike na čelu firme, Jana A. Batu (Jan A. Bat'a), Dominika Čiperu (Dominik Čipera) i Huga Vavrečku (Hugo Vavrečka), da se okrenu otvaranju fabrika u inostranstvu preko kojih bi bila snabdijevana ta tržišta. ${ }^{10}$ Pred izbijanje Drugog svjetskog rata firma Bata je zapošljavala oko 65.000 ljudi širom svijeta, odnosno bila zastupljena u preko 90 zemalja (preko sestrinskih firmi, proizvodnih pogona i trgovačkih mreža). ${ }^{11}$

Sa poslovnim uspjesima firme van granica Čehoslovačke u prvoj polovini dvadesetih godina ${ }^{12}$ došli su i prvi protesti organizovani od strane domaćih proizvođača i radničkih organizacija. Oni su počeli u Njemačkoj, da bi se proširili na Englesku, skandinavske zemlje i Jugoslaviju, a zatim na druge evropske i bliskoistočne zemlje. Protesti su imali formu demonstracija, širenja anti-Batinih pamfleta, organizovanih bojkota prodavnica i pritiska na vlasti u pojedinačnim zemljama, sa ciljem uvođenja protekcionističkih mjera. U nekim zemljama su uvedene različite mjere protiv Bate, pa je došlo i do zatvaranja prodavnica $u$ Poljskoj, Danskoj i Rumuniji u drugoj polovini te decenije. ${ }^{13}$ Između ostalog, firma je bila optuživana za socijalni damping i iskorištavanje radnika, pa je ova kompanija bila i u centru pažnje nekoliko cjelo-evropskih kongresa radničkih organizacija - u Pragu (1924), Parizu (1925), Londonu (1927), Ženevi (1930) i Beču (1931). ${ }^{14}$ Zahvaljujući Bati, Čehoslovačka je postala najveći svjetski izvoznik obuće u 1928. godini i tu poziciju je zadržala do izbijanja Drugog svjetskog rata. ${ }^{15}$ Ovakva ekspanzija je uzrokovala dalji talas akcija širom Evrope, među kojima su bile najznačajnije negativna novinska kampanja protiv kupovanja u Batinim prodavnicama kao i izdavanje pamfleta i knjiga, od kojih je

\footnotetext{
${ }^{9}$ Bohumil Lehár, Dějiny Batova koncernu (Praha: SNPL, 1960), 294. Sestrinske firme su osnovane u Poljskoj, Kraljevini SHS, Holandiji, Danskoj, Norveškoj, Velikoj Britaniji, a početkom tridesetih u Njemačkoj, Austriji, Švedskoj, Švajcarskoj, Francuskoj i drugdje.

${ }^{10}$ Zdeněk Pokluda, Ze Zlína do světa - př́běh Tomášse Bati = From Zlin into the World - The Story of Tomas Bata (Zlín: Nadace Tomáše Bati, 2015), 37; SOkA Zlín, f. Bata a. s., XXVI, k. 1835, inv. č. 70. U periodu 1929-1932. firma je osnovala fabrike u Otmutu (Njemačka), Borovu (Jugoslavija), Mohlinu (Švajcarska), Helmeku (Poljska) i Ilkuru (Francuska). U narednim godinama otvoreni su i pogoni u Konagaru (Indija), Tilburiju (Engleska) i Bestu (Holandija). Istovremeno je širena prodajna mreža, pa su tako do kraja tridesetih otvorene 3.272 prodavnice $\mathrm{u}$ inostranstvu.

${ }^{11}$ SOkA Zlín, f. Bat'a a. s., X, k. 1541, i. č. 118.

12 Jaroslav Pagáć, Tomáś Bata a 30 let jeho podnikatelské práce (Praha: Sfinx, 1926), 291. Već 1923. godine Bata je imao svoje prodavnice u Kraljevini SHS, Rumuniji, Danskoj, Holandiji, Poljskoj, Norveškoj, Velikoj Britaniji, SAD i Egiptu. U drugim zemljama produkti firme su distribuisani preko veleprodaje.

${ }^{13}$ SOkA Zlín, f. Bat'a a. s., I/3, inv. č. 29, k. 18, f. 343-346.

${ }^{14}$ B. Lehár, op. cit., 92, 94, 111-112, 146.

${ }^{15}$ Antonín Cekota, Geniální podnikatel Tomáš Bata (Toronto: Sixty-Eight Publishers, 1981), 258.
} 
najpoznatija bila Der unbekannte Diktator Thomas Bata, ${ }^{16}$ čije širenje je firma pokušala spriječiti i sudskim putem. ${ }^{17}$ Osim toga, u tadašnjoj antisemitskoj atmosferi koja je vladala širom Evrope, u pojedinim zemljama Bata je optuživan da je jevrejskog porijekla. ${ }^{18}$

I pojedine vlade su usvajale mjere protiv Bate, pa su tako u Švajcarskoj tokom 1934. ${ }^{19}$ i Francuskoj u 1936. ${ }^{20}$ godini usvojeni tzv. Lex Bata zakoni koji su imali za cilj sprječavanje dalje tržišne ekspanzije firme. U drugim zemljama su uvođene mjere usmjerene ka sprječavanju otvaranja Batinih fabrika, što je prije svega bio slučaj u Mađarskoj, Rumuniji i Bugarskoj. ${ }^{21}$ U pojedinim državama, poput Estonije, Letonije i Finske, anti-Batine mjere dovele su i do povlačenja firme iz tih zemalja tokom tridesetih godina. ${ }^{22}$

\section{Firma Bata u Kraljevini SHS/Jugoslaviji}

Prva obuća iz firme Bata u južnoslovenskim zemljama pojavila se još prije Prvog svjetskog rata. ${ }^{23}$ Ipak, zvanično nastupanje i širenje poslovanja u novoformiranoj Kraljevini SHS dogodilo se tek nakon Prvog svjetskog rata. Iako je do službenog formiranja firme došlo 1920. godine, sa osnivanjem Bata cipele $i$ koža $d$. d. u Zemunu, već 1919. godine Toma Maksimović ${ }^{24}$ je bio

${ }^{16}$ Rudolph Philipp, Der unbekannte Diktator Thomas Bata (Wien - Berlin: Agis - Verlag, 1928). Knjiga je potom prevedena na više evropskih jezika.

${ }^{17}$ Archiv Ministerstva zahraničních věci (dalje AMZV), fond (dalje f.) IV. sekce, k. 1080, sl. 35.

${ }^{18}$ Eduard Kubů, „Die Bata-Gefahr“: Anti-bat'ovská propaganda a bojkotové akce v Německu na přelomu 20. a 30. let 20. století“, u: Pocta Janu Janákovi: předsedovi Matice moravské, profesoru Masarykovy univerzity věnuji $k$ sedmdesátinám jeho přátelé a žáci, ed. Bronislav Chocholáč i Jiř́i Malíř (Brno: Matice moravská, 2002), 529-531.

${ }^{19}$ Karl Schib, Geschichte des Dorfes Möhlin (Erschienen Thayngen: Augustin, 1959), 277-280.

${ }^{20}$ Alain Gatti, Chaussures les hommes qui vont pieds nus: Bata-Hellocourt, 1931-2001: enquete sur la memoire industrielle et sociale (Metz: Serpenoise, 2004), 151, 173, 334.

${ }^{21}$ AMZV, f. IV. sekce, k. 1081, sl. 1.

${ }^{22}$ AMZV, f. IV. sekce, k. 1082, sl. 7.

${ }^{23}$ K. Hrelja i M. Kaminski, $n$. d., 32.

24 Toma Maksimović (Brčko, 29. mart 1895 - Beograd, 16. februar 1958), uspješni privrednik i društveni radnik. Od 1919. radio je u firmi Bata i svojim sposobnostima se od poslovođe prodavnice uzdigao do položaja generalnog direktora firme Bata u Jugoslaviji. Osim rukovođenja fabrikom, bio je na čelu Opštine Borovo, Srpskog privrednog društva Privrednik, Sokola u Borovu i drugih organizacija i udruženja. Nakon Aprilskog rata uhapšen je od strane ustaških vlasti da bi u junu 1941. bio deportovan u Beograd, gdje je potom u oktobru 1941. preuzeo funkciju izvanrednog komesara za izbjeglice i preseljenike u vladi generala Milana Nedića. Tokom tri godine svog djelovanja na čelu Komesarijata, organizovao je prihvat nekoliko stotina hiljada izbjeglica u Srbiji. Po oslobađanju Beograda uhapšen je i osuđen na četiri godine zatvora sa prinudnim radom, da bi nakon amnestije u decembru 1945. bio pušten. Ponovo je uhapšen 7. februara 1946, i osuđen kao ,narodni neprijatelj“ na pet godina zatvora i gubitak građanskih prava na tri godine. Zatvorsku kaznu je odslužio u Sremskoj Mitrovici, odakle je izašao 12. januara 1951. Nakon izlaska iz zatvora radio je kao rukovodilac trgovine na veliko u Bosni i Hercegovini, zatim u spoljnotrgovinskom preduzeću „Balkanija“, da bi poslednje godine života proveo u tvornici „Planika“" u slovenačkom Kranju, odakle se teško bolestan krajem 1957. godine vratio u Beograd, gdje je umro 16. februara 1958. Viši sud u Novom Sadu je donio odluku 
angažovan kao poslovođa Batine prodavnice u Beogradu. ${ }^{25}$ Poslije Beograda, novoosnovana firma je vrlo brzo otvorila svoje prodavnice u Zagrebu, Sarajevu, Novom Sadu, Osijeku, Velikom Bečkereku (danas Zrenjanin), Brodu na Savi (danas Slavonski Brod), Somboru, Dubrovniku, Mostaru, Travniku i Brčkom. ${ }^{26}$

U prvoj deceniji svog postojanja na jugoslovenskom tržištu firma Bata se suočavala sa raznim poteškoćama koje su otežavale razvoj i dalje širenje njenog poslovanja (npr. nepouzdanim poslovođama ${ }^{27}$ ili povećanjem carinskih $\left.\operatorname{tarifa}^{28}\right) .{ }^{29}$ Međutim, čak i u takvim okolnostima njena prodajna mreža je postepeno širena, pa je tako od 1922. do 1931. godine bilo otvoreno 110 prodavnica širom zemlje. ${ }^{30}$ Krajem dvadesetih godina firma Bata je u Jugoslaviju godišnje izvozila između 1,2 i 1,5 miliona pari obuće. ${ }^{31}$ Uspjesima firme u prodaji tih godina pogodovali su napadna propaganda i inovativno reklamiranje - npr. tokom pijačnih dana u Skoplju firma je unajmljivala romske muzičare da reklamiraju Batu sa muzikom, bubnjevima i talambasima. ${ }^{32}$

Usljed posljedica Velike ekonomske krize i uvedenih protekcionističkih mjera rukovodstvo firme je krajem 1920-ih pristupilo osnivanju proizvodnih pogona na teritoriji Kraljevine Jugoslavije, pa su tako već u 1931. godini počele sa radom fabrike u Apatinu ${ }^{33}$ i Borovu. U Borovu je podignut i prvi fabrički grad na teritoriji tadašnje države. ${ }^{34}$ Po Sergiju Dimitrijeviću, tempo industrijskog razvitka u kožarskoj industriji tokom međuratnog perioda godišnje je iznosio 1,2\%, osim 1931. kada je zbog Bate dostigao 44,6\%, ${ }^{35}$ što ilustruje koliki je

o njegovoj rehabilitaciji 9. marta 2009. Više o Tomi Maksimoviću u: M. Balaban, Podnikáni firmy Bat’a v Jugoslávii, 203-205; D. Živić i dr., n. d., 351-364.

${ }^{25}$ SOkA Zlín, f. Bat'a a. s., XXVII, k. 1023, inv. č. 14, por. č. 9.

${ }^{26}$ Arhiv Jugoslavije (AJ), fond 65, Ministarstvo trgovine i industrije, fascikla 702, arhivska jedinica 1436, Zapisnik sa prve redovne godišnje skupštine društva, 11. jun 1922.

${ }^{27}$ AJ, 65-702-1436, Izvještaj upravnog odbora o radu društva u 1922. godini, 15. avgust 1923.

${ }^{28}$ Tokom 1925. godine Kraljevina SHS je uvela nove carinske tarife, među kojima je bilo i povećanje carine na uvoz obuće, koja je tako činila skoro $40 \%$ od ukupne cijene dovezene obuće. $\mathrm{Na}$ ime te takse samo u 1929. godini ubrano je 45.331.273 dinara. AMZV, f. IV sekce, kart. 1081, obal. II, č. j. 9693/30, O továrny fmy T. A. Bata v Jugoslávii, 28. avgust 1930.

${ }^{29}$ Detaljan prikaz prve decenije poslovanja firme Bata u Jugoslaviji u: M. Balaban, Podnikáni firmy Bat’a v Jugoslávii, 41-68.

${ }^{30}$ SOkA Zlín, f. Bat'a a. s., XXVI Export-vyvoz, k. 1835, inv. č. 70, Jugoslávie.

${ }^{31}$ M. Jemelka i O. Ševeček, op. cit., 384.

32 Branko Petranović, Istorija Jugoslavije 1918-1988, Knjiga prva - Kraljevina Jugoslavija (Beograd: Nolit, 1988), 75.

33 O kratkotrajnom radu Batine fabrike u Apatinu više u: M. Balaban, Podnikáni firmy Bata v Jugoslávii, 68-72.

${ }^{34}$ U fabričkom gradu Borovo, nastalom po urbanističkom konceptu Františka L. Gahure (František Lýdie Gahura), koji su realizovali Antonjin Vitek (Antonín Vítek) i Vladimir Karfik (Vladimír Karfík), u vrlo kratkom periodu, do početka Drugog svjetskog rata, izgrađeno je 19 fabričkih zgrada i 147 stambenih objekata sa 490 stanova. Ti stanovi su za standarde radničkog smještaja tog doba bili veoma moderni, jer su imali struju, tekuću vodu i kanalizaciju. U periodu 19311939. izgrađeno je i 20 drugih objekata, između ostalih Društveni dom, Dom kulture, internati, sportska igrališta, kupalište, klizalište, tri škole i jedna predškolska ustanova za djecu radnika, ambulanta, aerodrom i drugi objekti. M. Balaban, Podnikáni firmy Bat’a v Jugoslávii, 87-89.

${ }^{35}$ S. Dimitrijević, $n$. d., 27. 
bio značaj osnivanja fabrike te godine. Do kraja tridesetih godina firma je postala najveći proizvođač obuće na cijelom području Kraljevine Jugoslavije. Na vrhuncu poslovanja, 1939. godine, u fabrici u Borovu je bilo zaposleno 3.500 radnika, koji su proizveli 7,26 miliona pari obuće. Firma je te godine imala i oko 550 prodavnica koje su zapošljavale dodatnih 1.330 osoba, a pokrivala je $90 \%$ proizvodnje i prodaje obuće u državi. ${ }^{36}$

Krajem te decenije došlo je do daljeg širenja poslovnih aktivnosti firme na jugoslovenskom tržištu. Naime, zbog kraja čehoslovačke Prve republike u oktobru 1938, ${ }^{37}$ firma Bata je upravo u Kraljevini Jugoslaviji vidjela moguće izlazno rješenje. Iz tih razloga je portfolio firme proširen sa više industrijskih postrojenja i oglednom farmom u Hamzaliji, kod Strumice u Makedoniji, gdje su se trebali proizvoditi poljoprivredni artikli i industrijske biljke za koncern. Osim toga, preduzeće je kupovalo zemljište za nove fabrike, rudnike, talionice željeza i druge pogone. Sve te ambiciozne planove su prekinule okupacija i podjela Kraljevine Jugoslavije. Nakon tegobnih ratnih godina, imovina firme Bata je nacionalizovana, a preimenovano preduzeće, Borovo, jugoslovenski kombinat gume $i$ obuće, nastavilo je i u poslijeratnom periodu razvoj te postalo jedan od deset najvećih privrednih subjekata na području cijele države. Neposredno pred raspad Socijalističke Federativne Republike Jugoslavije preduzeće je zapošljavalo preko 20.000 ljudi i bilo je osnovni pokretač ekonomskog razvoja cijele istočne Slavonije. Tokom rata u Hrvatskoj (1991-1995) kombinat i naselje Borovo su doživjeli teška razaranja, od kojih se ni do danas nisu oporavili. ${ }^{38}$

\section{Anti-Batini protesti tokom 1920-ih godina}

Ekspanzija firme Bata na jugoslovenskom tržištu dovela je do toga da su obućarski slojevi stanovništva, već ekonomski ugroženi tekućim modernizacijskim procesima u proizvodnji, bili izloženi još većem riziku od socijalne deprivacije. Obućarski sloj u Kraljevini SHS/Jugoslaviji je zbog svoje brojnosti bio posebno važan i egzistencijalna ugroženost tog društvenog sloja se odražavala na cjelokupne socijalne procese u državi. ${ }^{39}$ Trend povećanja uvoza obuće iz inostranstva, od kojeg je veliki dio otpadao na obuću proizvedenu u Čehoslo-

\footnotetext{
${ }^{36}$ AJ, fond 17, Ministarstvo industrije FNRJ, fascikla 103, arhivska jedinica 103, Pregled koncerna Bata Borovo, 1945.

${ }^{37}$ Period između oktobra 1938. i 15. marta 1939. poznat je u češkoj istoriografiji kao Druga republika, kada nestaju demokratske ustanove Prve republike (1918-1938) i zavode se autoritarne mjere i zakoni. Druga republika je prestala da postoji uvođenjem njemačkog protektorata Češke i Moravske (Protektorat Böhmen und Mähren), kao i odvajanjem Slovačke.

${ }^{38}$ M. Balaban, Podnikáni firmy Bata v Jugoslávii, 195-196.

${ }^{39}$ Po podacima Ministarstva trgovine i industrije u Jugoslaviji je sredinom 1930-ih godina bilo oko 2.600 zanatlijskih i industrijskih preduzeća koja su se bavila proizvodnjom i popravkom obuće. Po istom izvoru u cijeloj zemlji je u tom trenutku radilo 15.000 obućarskih majstora i oko 60.000 kožarskih radnika. To je bilo značajno smanjenje u odnosu na 1928. godinu, kada je po podacima istog ministarstva u Jugoslaviji u kožarskoj industriji radilo 127.000 radnika. AJ, 65-702-1436, Motivacija za donošenje Uredbe o proizvodnji, opravci i prodaji obuće Ministarskog saveta Kraljevine Jugoslavije, 21. jun 1936.
} 
vačkoj i Zlinu, poklopio se sa krizom domaće kožarske industrije u drugoj polovini dvadesetih godina. ${ }^{40}$ Konkurencija jeftine uvozne obuće, domaće zanatlije je dovela u veoma nepovoljnu poslovnu situaciju. Zbog pada prodaje obuće bili su prinuđeni da se skoro isključivo preorijentišu na njenu popravku, a kao rezultat toga morali su da smanjuju broj radnika i/ili da ga drže na minimumu. Pored toga, da bi uopšte opstali u struci, morali su iznaći/usvojiti sistem racionaln(ij)e proizvodnje obuće. Plaćanje poreskih i ostalih obaveza poput iznajmljivanja prostora, radničkih plata, dodatno je opterećavalo poslovanje većine domaćih zanatlija, pa su mnogi od njih napuštali struku i prelazili u redove proleterijata. Navedene okolnosti su vodile ka intenziviranju socijalnih tenzija, tako da je firma Bata u Kraljevini SHS, osim slabe likvidnosti i zavisnosti od pomoći majke firme iz Zlina, ${ }^{41}$ bila suočena i sa organizovanim otporom zanatlija i domaćih proizvođača obuće, koji su se žalili na nelojalnu konkurenciju, damping cijene i tražili od domaćih vlasti da ih zaštiti od nestajanja. Obućari iz Vojvodine i Srema, čije udruženje je predstavljalo 1.300 malih zanatlija, u rezoluciji od 23. maja 1926. zahtijevali su da se ukinu sve povlastice firmi Bata i da se uvoz obuće iz inostranstva putem uvođenja zaštitnih kvota svede na minimum. ${ }^{42}$ Takođe, tražili su zabranu poslovanja radionica za popravku obuće pri prodavnicama firme Bata, ali i zabranu daljeg odlaska mladih ljudi na stručnu obuku u Zlin (što je u to vrijeme posmatrano kao izrabljivačka praksa). ${ }^{43}$ Pored toga, pomenuta i slične rezolucije sadržavale su i zahtijeve za rigorozniju poresku kontrolu poslovanja firme Bata, koja je često optuživana za izbjegavanje ili umanjeno plaćanje poreza, odnosno za pooštrenu carinsku kontrolu robe koja je dolazila na firmu Bata. ${ }^{44}$

U junu 1926. održan je Kongres obućara Srbije u Beogradu na kojem je, između ostalog, zatraženo da se prilikom sklapanja trgovinskih ugovora, čak i sa prijateljskim zemljama, posebna pažnja posveti količini i vrijednosti obuće koja se mogla uvesti u zemlju. ${ }^{45} \mathrm{U}$ suštini, osnovni zahtijevi zanatlija na tom prote-

${ }^{40}$ AJ, 65-702-1436, Peticija Saveza postolarskih, čizmarskih i opančarskih obrtnika u Zagrebu, 18. mart 1931.

${ }^{41}$ Tokom prvog dijela dvadesetih godina 20. vijeka, firma Bata je u Jugoslaviji poslovala na negativnoj granici. Uspijevala je da posluje samo zbog finansijske pomoći matične firme iz Zlina koja joj je, pored ostalog, prodavala obuću po ispod-tržišnim cijenama. Situacija se ipak pozitivno promijenila u drugoj polovini te decenije.

42 AJ, 65-702-1436, Rezolucija obućara Vojvodine i Srijema, 23. maj 1926.

${ }^{43}$ Od 1925. godine otvorena je Batina škola rada (Bat’ova škola práce) u Zlinu, gdje su na obuku dolazili polaznici iz cijelog svijeta, da bi se naučili radu u Batinim prodavnicama i tvornicama, da bi se potom vratili u svoje zemlje i tamo radili za firmu. Pohađanje škole je trajalo tri godine, tokom kojih su đaci stanovali u internatima, učili i radili u zlinskim fabrikama. Firma Bata je i inače preferirala zapošljavanje radne snage koju je sama obučila i koja je poticala iz ruralnih regiona. Razlozi za to su ležali u nepovjerenju prema radnicima iz gradskih sredina koji su već prošli obuku i usvojili sisteme rada različite od Batinih, kao i činjenici da su oni uglavnom bili članovi sindikata. U Batinom sistemu, od generalnog štrajka u Zlinu u 1906. godini nije bilo dozvoljeno postojanje drugih sindikata osim onih koje bi osnovala sama firma. Ova politika je napuštena tek krajem tridesetih i početkom četrdesetih godina 20. vijeka.

${ }^{44}$ M. Balaban, Podnikáni firmy Bata v Jugoslávii, 51.

${ }^{45}$ AJ, 65-702-1436, Kongres obućara u Beogradu, 23. juni 1926. 
stnom zboru nisu izlazili iz okvira koje su postavljali i drugi skupovi. Među njima se isticala potreba ukidanja svih povlastica firmi Bata, kontingentiranje obuće uvezene iz inostranstva, kao i da se prilikom oporezivanja te kompanije ne oporezuje samo centrala firme već i da sve filijale takođe plate svoje obaveze, poput zakonskog prometnog poreza, opštinskog prireza, dohodarine i ostalih dažbina. ${ }^{46}$ Kao najveći problem je navođena Batina praksa otvaranja radionica za popravku obuće, koja je izravno prijetila egzistenciji desetina hiljada već siromašnih obućara. U uslovima niske kupovne moći stanovništva, koje je godišnje po glavi stanovnika kupovalo manje od jednog para obuće, upravo su popravke obuće bile glavni izvor prihoda za male zanatlije. Osim toga, traženo je da se smanji taksa na uvoz kože, kako bi i domaći obućari mogli prodavati svoje proizvode po povoljnijim cijenama, kao i da se utvrdi da li firma Bata ima povlastice u vidu povraćaja sredstava uplaćenih na carini, i ako ima da se iste ukinu. ${ }^{47}$ Djelovanju firme Bata, čak i u doba kada nije imala široku prodajnu mrežu koju je izgrađena u tridesetim godinama, pripisivalo se zatvaranje fabrika obuće u Nišu, Sisku, Apatinu kao i prestanak rada tvornice cipela Radenska u Zagrebu. ${ }^{48}$ Zanatlije su se posebno žalile na nedopušten način reklamiranja, kome domaća obućarska industrija nije mogla parirati. U svojim žalbama su ukazivali i na to da je u svojim oglasima firma Bata navodila lažne podatke o visini jugoslovenske carine na uvoz obuće, te da je time implicirala da krivicu za visoke cijene obuće snosi jugoslovenska vlada svojom protekcionističkom politikom. ${ }^{49}$

\section{Anti-Batini protesti u 1930-im godinama}

Kako su se dvadesete godine bližile kraju, broj anti-Batinih peticija i protesta se sve više povećavao. Sa pogoršanjem ekonomskog stanja preostalih sitnih zanatlija isključivi krivac za njihov težak socijalni položaj tražio se u firmi Bata, a ne u neminovnosti nestajanja tehnološki zaostalog, zanatlijskog načina proizvodnje. Još 1929. godine u Jugoslaviju je uvezeno obuće u iznosu od 65 miliona dinara. ${ }^{50}$ Tokom tih protesta, poseban akcenat je bio na preuveličavanju broja radnika u kožarskoj industriji i osoba koje su od njih zavisile. Preko toga je ostvarivan pritisak na vlasti, koje su se plašile posljedica oštrih socijalnih konflikata, pa je taj broj povećavan i na 200 hiljada $^{51}$ ili čak 300 hiljada ljudi, ${ }^{52}$ što bi predstavljalo $1,5-2 \%$ cjelokupnog stanovništva države. ${ }^{53}$

\footnotetext{
${ }^{46}$ AJ, 65-146-481, Rezolucija obućara Južne Srbije, 30. juni 1926. Tokom cijelog perioda postojanja firme Bata u Jugoslaviji ovo je bila jedna od glavnih optužbi od strane malih zanatlija i domaćih industrijalaca. Oni su tvrdili da tako velika firma plaća nesrazmjerno male poreze i da je sav teret oporezivanja pao na njihova pleća, dok s druge strane nisu bili nimalo zaštićeni od strane države.

${ }^{47}$ AJ, 65-146-481, Rezolucija obućara Južne Srbije, 30. juni 1926.

${ }^{48}$ AJ, 65-702-1436, Čsl. Tvornica cipela - nedopušteni način reklame, 9. juli 1926.

${ }^{49}$ Isto.

${ }^{50}$ AJ, 65-702-1436, Peticija Zveza obrtnih zadrug v Ljubljani, 5. septembar 1930.

${ }^{51}$ Isto.

52 AJ, 65-702-1436, Peticija saveza obućarske i kožarske industrije Kraljevine Jugoslavije, 30. decembar 1930 .
} 
Tolike brojke su naravno bile pretjerane, pošto bi to značilo da je skoro svaka 50. osoba u pretežno zemljoradničkoj državi živjela od jedne privredne grane koja je bila relativno nerazvijena. ${ }^{54}$

U kampanju protiv Bate uključivale su se i političke ličnosti, pa je tako ban Dunavske banovine Radoslav Dunjić, u ime građana Kruševca iz kojeg je poticao, pisao ministru trgovine i industrije Juraju Demetroviću da se nešto mora preduzeti po pitanju firme Bata i zaustaviti njena ekspanzija koja je prijetila egzistenciji domaćih zanatlija i njihovih porodica. ${ }^{55}$ Protestovali su i obućari iz Vardarske banovine, u čiju zaštitu je stao i tadašnji ohridski episkop Nikolaj Velimirović, koji je tražio od bana i njegovog zamjenika da zaustave dalje otvaranje Batinih prodavnica i radionica za popravku obuće u Makedoniji. ${ }^{56}$

Problem kožarske industrije nije zaokupljao samo zanatlije iz te struke već i mnogo širu zajednicu, pa su i iz tih razloga i nacionalna udruženja, poput Hrvatskog društva obrtnika, protestovala protiv Bate. ${ }^{57}$ Kampanja se posebno pojačavala upravo početkom 1930-ih godina sa Velikom ekonomskom krizom. Moguće podizanje fabrike za proizvodnju obuće nije samo zabrinjavalo i zanimalo male zanatlije, već i Industrijsku komoru, koja je takođe iskazivala interesovanje da li je i kada firma podnijela zahtjev za dozvolu za izgradnju. ${ }^{58}$ Put ka podizanju fabrike obuće je bio otvoren odobrenom promjenom pravila dioničkog društva Bata od strane Kraljevske banske uprave u Zagrebu 21. jula 1930, kojom je dozvoljeno da društvo može voditi i proizvodnju cipela. ${ }^{59}$ Iako su time otklonjene zakonske prepreke, do samog podizanja fabrike je predstojao dug put. Firma Bata je postojeće zakonske odredbe, koje su otežavale uvoz mašina za fabriku, pokušala zaobići tako što je tražila dozvolu za uvoz mašina za radionice za popravku obuće u januaru 1931. godine. Po mišljenju Ministarstva trgovine i industrije to nisu bile mašine za popravku već za proizvodnju obuće, čime se pripremao teren za podizanje fabrike u budućnosti. Zakonski propisi su dopuštali da trgovačka preduzeća mogu imati manje radionice za ograničenu obradu gotove robe koju su prodavali. To je omogućilo firmi Bata da otvori radionice za popravku obuće, što takođe po mišljenju nadležnih ustanova nije bilo ispravno, pošto se u tim radionicama nije obrađivala i prilagođavala gotova roba pred prodaju, već se popravljala prodana obuća. Iz tih razloga je nadležno ministarstvo predlagalo

\footnotetext{
${ }^{53}$ U Jugoslaviji je po popisu iz 1931. godine živjelo 13.982 .000 ljudi.

${ }^{54}$ Od prethodno navedenog ukupnog broja stanovnika Jugoslavije, 76,58\% se bavilo poljoprivredom, šumarstvom i ribolovom, što je u apsolutnim brojevima iznosilo 10.670 .565 osoba. Od industrije i zanatstva je živjelo $11 \%$ stanovništva, što je u apsolutnim brojkama iznosilo oko 1.533.052. Ukoliko bi se brojevi koje su navodili anti-Batine interesne grupe uzimale relevantnim, onda bi se došlo do zaključka da je oko 1/5 ili 1/6 stanovništva zavisnog od industrije i zanatstva živjelo od kožarske industrije. Ipak, ove brojke govore da bi tim podacima trebalo pristupiti sa rezervom. Više o socijalnoj strukturi stanovništva u: B. Petranović, $n$. d., 56-86.

${ }_{55}$ AJ, 65-702-1436, Dopis za ministra trgovine i industrije, 18. juli 1930.

${ }^{56}$ AJ, 65-702-1436, Firma Bata u Južnoj Srbiji, 21. februar 1931.

${ }^{57}$ AJ, 65-702-1436, Peticija Saveza hrvatskih obrtnika, 27. maj 1931.

${ }^{58}$ AJ, 65-702-1436, Dopis Industrijske komore Beograda, 7. novembar 1930.

${ }^{59}$ AJ, 65-702-1436, Dopis Ministarstva trgovine i industrije - predsjedniku Ministarskog savjeta Kraljevine Jugoslavije, 6. februar 1931.
} 
Ministarskom savjetu da se nekim od mjera koje su tražili potpisnici raznih peticija i zahtjeva izađe u susret, u granicama zakonskih mogućnosti. Po tom osnovu su predložene mjere za zabranu rada radionica, dok se zabrana podizanja fabrike obuće nije mogla sprovesti po postojećim zakonskim propisima. I samo Ministarstvo trgovine i industrije je isticalo da bi otvaranje takve moderne fabrike znatno naškodilo sitnim zanatlijama i ostalim domaćim proizvođačima obuće, ali da bi rad te tvornice sa domaćom radnom snagom, koja bi koristila sirovine iz Jugoslavije, zapošljavala i plaćala porez u samoj državi, bio u krajnjoj liniji koristan za državu. Firma Bata je dotada uvozila obuću iz inostranstva, a podizanjem fabrike u zemlji novac koji je odlazio iz države ostajao bi u njoj. Takođe, iako bi ta fabrika bila u stranim rukama, što se izbjegavalo u slučaju privrednih grana važnih za državnu odbranu, u koje je spadala i obućarska industrija, ona bi ipak dolazila iz prijateljske i savezničke Čehoslovačke. ${ }^{60}$ Pitanje Bate je potom postalo jedna od tema kojom se bavio ekonomsko-finansijski komitet Ministarskog savjeta Kraljevine Jugoslavije, koji je morao naći način kako da smiri proteste zanatlija i da istovremeno ne izazove probleme u odnosima sa Čehoslovačkom. ${ }^{61}$

Ekspanzija firme Bata na jugoslovenskom tržištu prisilila je domaće zanatlije i prodavce obuće da se svojim žalbama obraćaju poslanicima u Narodnoj skupštini, koji su ih uobličavali i prezentovali centralnim organima $u$ Beogradu. U tim žalbama su, osim uobičajenih motiva o ugrožavanju egzistencije obućara i njihovih porodica, počeli da preovladavaju detalji o neplaćanju ili nesrazmjerno malom plaćanju poreskih obaveza za tako veliku firmu. Tako je poslanik Milan Metikoš, u svojoj predstavci Ministarstvu trgovine i industrije, navodio podatak da je firma Bata, i pored svog prometa od preko 300 miliona dinara u 1933, platila svega 100.000 dinara društvenih poreza i da takav nesrazmjerno mali porez ide kako na štetu Jugoslavije tako i životno ugroženog obućarskog sloja stanovništva i njihovih porodica. Firma Bata se od takvih optužbi branila statistikom sveukupno plaćenih poreskih davanja, koja su umnogome premašivala navedenu cifru. Firma je u svojoj argumentaciji navodila da je izmjenom poreskih zakona i prebacivanjem njihovog težišta sa neposrednih na posredne poreze, kao i njihovog višestrukog povećanja tokom poslednje decenije, ova brojka u stvari nekoliko stotina puta veća. Tako su po njima posredni porezi, carina, trošarina i porez na luksuz postali mnogo važniji od ranije najznačajnijeg načina obračunavanja, poreza na dobit. Kao dokaz navodili su tabelu, prethodno dobijenu nakon kontrole Ministarstva

${ }^{60}$ AJ, 65-702-1436, Dopis Ministarstva trgovine i industrije - predsjedniku Ministarskog savjeta Kraljevine Jugoslavije, 6. februar 1931.

${ }^{61}$ Odnosi sa Čehoslovačkom, koja je bila saveznik u okviru Male antante kao i jedan od najvažnijih trgovinskih partnera Kraljevine Jugoslavije, bili su od izuzetnog značaja za prvu jugoslovensku državu. O ekonomskim odnosima Jugoslavije i Čehoslovačke više u neobjavljenoj disertaciji Milana Balabana, "Yugoslav-Czechoslovak Economic Relations between 1918 and 1938 year" (Doktorská disertace, Filozofická fakulta Masarykové univerzity, Brno, 2016); Milan Balaban, "General overview of Yugoslav-Czechoslovak economic and trade relations for period between 1918 and 1938”, Slovanský přehled, 102, br. 3, (2016), 503-612. 
finansija početkom 1934, i čak tvrdili da je po tim podacima firma Bata bila najveći poreski platiša u Jugoslaviji 1933. godine. ${ }^{62}$

\begin{tabular}{|l|r|r|r|l|l|r|}
\hline Godina & $\begin{array}{l}\text { Neposredni } \\
\text { porezi }\end{array}$ & $\begin{array}{l}\text { Kaldrmija i } \\
\text { opštinski } \\
\text { porez }\end{array}$ & Carina & Podvoz & $\begin{array}{l}\text { Pošta, } \\
\text { telegraf, } \\
\text { telefon }\end{array}$ & Ukupno \\
\hline 1929. & 402.822 & 398.095 & 18.142 .597 & $\begin{array}{l}\text { knjiženo u } \\
\text { carini }\end{array}$ & 303.343 & 19.246 .857 \\
\hline 1930. & 870.365 & 1.275 .022 & 24.203 .288 & 1.675 .952 & 250.787 & 28.275 .414 \\
\hline 1931. & 1.104 .868 & 2.375 .754 & 46.834 .532 & 2.046 .955 & 785.097 & 53.147 .206 \\
\hline 1932. & 896.431 & 2.434 .460 & 12.879 .051 & 3.000 .671 & 911.278 & 20.621 .842 \\
\hline 1933. & 6.899 .825 & 5.310 .596 & 3.152 .754 & 9.332 .673 & 856.109 & 25.551 .967 \\
\hline Ukupno & 10.174 .311 & 12.293 .927 & 105.212 .232 & 16.056 .254 & 3.106 .564 & 146.843 .285 \\
\hline \multicolumn{7}{|c|}{ Poreska davanja firme Bata za period 1929-1933. u dinarima } \\
\hline
\end{tabular}

Kao što se može vidjeti iz ove tabele, iako su poreska davanja firme Bata bila mnogo veća od navođenih 100.000 dinara koje su im pripisivali njihovi protivnici, ipak je najveći dio, skoro $72 \% \mathrm{u}$ analiziranom periodu, dolazio od uplaćenih carina, koje su u periodu nakon osnivanja sopstvenih proizvodnih pogona ubrzano opadale. Tako je i prihod od uplaćenih sredstava u 1933. godini bio više nego duplo manji od perioda samo dve godine ranije, pa vjerovatno ni tvrdnja da je u toj godini firma Bata bila najveći poreski obveznik u zemlji nije istinita.

Tokom tridesetih godina vlasti su pokušale da ispune neke od najurgentnijih zahtijeva zanatlija, na primjer da onemoguće Batinu praksu otvaranja radionica za popravljanje obuće. U tom kontekstu je Ministarski savjet Kraljevine Jugoslavije, na zahtjev ministra trgovine i industrije, zabranio rad radionica za popravljanje obuće i odjeće industrijskih preduzeća, odlukom od 3. avgusta 1934, koja je stupila na snagu 18. novembra te godine. Do tada su morale biti zatvorene sve radionice u sklopu prodavnica. ${ }^{64}$ Firma Bata je ipak ovu uredbu zaobišla. ${ }^{65}$ Tako je i nakon te odluke, ali i pooštravanja kontroli i kazni, firma nastavila sa otvaranjem novih radionica, pa je na jedan takav slučaj upozoravalo Udruženje zanatlija grada Zagreba, to jest da i pored zabrane firma Bata planira da otvori radionicu za popravku obuće u sklopu svoje prodavnice u zagrebačkoj Sokolskoj ulici. ${ }^{66}$ Najučestaliji način zaobilaženja ove uredbe bio je prevođenje radionica na poslovođe prodavnica u kojima su se nalazile ili sklapanje ugovora sa obućarima, kojima su iznajmljivani prostor i mašine u sklopu tih prodavni-

${ }^{62}$ AJ, 65-146-481, Odgovor firme Bata na interpelaciju narodnog poslanika dr. Milana Metikoša, 30. juni 1934.

${ }^{63}$ AJ, 65-146-481, Statistika poreskih davanja firme Bata za period 1929-1933, 30. mart 1934. Nažalost, pošto nam podaci o najvećim poreskim obaveznicima za 1933. godinu nisu dostupni, ne možemo znati da li su ove tvrdnje imale stvarnu osnovu.

${ }^{64}$ Hrvatski državni arhiv (HDA), fond Savska banovina (f. SB), 91-151, Prepis Odluke o zabrani popravljaonica industrijskih preduzeća, 10. avgust 1935.

${ }^{65}$ HDA, f. SB, 91-151, Izigravanje odredbe o zabrani popravljanja odjeće i obuće po industrijskim radnjama, 22. novembar 1934.

${ }^{66} \mathrm{HDA}$, f. SB, 91-151, Bata d. d. - otvaranje nove filijale (popravljaone) u Zagrebu, 26. avgust 1934. 
ca. ${ }^{67}$ Banske uprave su došle $i$ do posjeda ugovora kojima su bili regulisani ti odnosi. $^{68}$ Registrovane zanatlije, sa majstorskom dozvolom, iznajmljivale su prostor, koji je morao biti fizički odvojen od prodavnice, a osim toga su preuzimali i opremu, na kojoj je morao biti vidno istaknut naziv „Bata“. Takođe, obućari su plaćali kaparu u iznosu od 500 do 5.000 dinara (u zavisnosti od tipa prodavnice). Sav materijal su morali nabavljati od firme Bata, i po odredbama ugovora obavezno su primali svu obuću Batine proizvodnje. ${ }^{69}$ Sačuvan je, na primjer, ugovor kojim je firma iznajmila obućaru Pavlu Sajleru iz Vinkovaca prostor i mašine u okviru svoje prodavnice za popravljanje obuće za mjesečni iznos od 200 dinara. ${ }^{70}$ Ovakva praksa je predstavljala indirektno kršenje navedene zakonske odredbe i dovela je do pojačanih žalbi zanatlijskih udruženja i do temeljnijih kontrola od strane vlasti, koje su zatim prvo pribjegavale upozorenjima, a onda sudskim odlukama i novčanim kaznama, kako za firmu Bata, tako i za ugovorne obućare. ${ }^{71}$ Ove kazne su uključivale zabrane daljeg djelovanja, novčane kazne za nedozvoljen rad i plaćanje sudskih troškova. Ipak u nekim slučajevima viši sudovi su stajali na stranu Bate i novih majstora, koji su pod svojim imenom preuzimali i dalje vodili radionice za popravku obuće. ${ }^{72}$ Određene uspjehe u otporu prema ekspanziji firme Bata na jugoslovenskom tržištu zanatlije su postigle i u pojedinim banovinama. Nakon niza protesta zanatlija Kraljevska banska uprava Dunavske banovine je donijela odluku da se firmi Bata zabrani prodaja robe po vašarima. ${ }^{73}$ Pomenute manifestacije, naročito po-

${ }^{67}$ HDA, f. SB, 91-151, Izigravanje odredbe o zabrani popravljanja odjeće i obuće po industrijskim radnjama, 22. novembar 1934.

${ }^{68}$ AJ, 65-146-181, Prepis cirkulara br. 120, 15. novembar 1934.

${ }^{69}$ HDA, f. SB, 91-151, Ugovor o iznajmljivanju radionice.

${ }^{70}$ HDA, f. SB, 66-151, Prepis ugovora o podnajmu lokala, 22. maj 1935. Po tom ugovoru navedeni obućar se obavezivao da će popravljati svu obuću Batine proizvodnje, kao i da neće prodavati u svojoj radnji nikakvu obuću sem one koju sam izradi. Firma mu je iznajmila mašine, kalupe, kao i namještaj za radionicu u vrijednosti od 11.510 dinara. Kasnije je odlukom suda, nakon žalbe Udruženja zanatlija iz Vinkovaca, Sajler kažnjen sa 4.000 dinara kazne, kao i firma Bata istim iznosom zbog sklapanja navedenog ugovora. HDA, f. SB, 66-151, Kazneni postupak protiv Pavla Sajlera i firme Bata, 18. maj 1935.

${ }^{71}$ HDA, f. SB, 91-151, Bata d. d. - prestup uredbe o zabrani popravljanja obuće ind. preduzeća, 19. novembra 1935. Na primjer, u prodavnici u Zagrebu, Ilica 10, u samom centru grada je pregrađena dotadašnja prodavnica i od nje odvojene prostorije u koje je smještena radionica za popravljanje obuće, koja se vodila na ime Batinog bivšeg poslovođe, obućarskog majstora Đuru Podunajca. U nju su upućivane sve mušterije, kao i roba koja je preuzimana na popravljanje. Na osnovu tužbe Udruženja zanatlija grada Zagreba kao i Zanatske komore, gradsko poglavarstvo je zabranilo dalji rad Podunajcu i dalje popravljanje obuće od strane firme Bata.

${ }^{72}$ Tako je Upravni sud u Beogradu poništio presudu izrečenu obućaru Svetomiru Stepanoviću iz Šida koji je na svoje ime preuzeo Batinu radionicu u tom gradu. Sresko načelništvo ga je kaznilo sa 300 dinara globe, a takođe i firmu Bata sa 7.000 dinara zbog prikrivanja nelegalne djelatnosti. AJ, 65-146-481, Presuda Svetomiru Stepanoviću i firmi Bata d. d., 17. septembar 1935.

${ }^{73}$ AJ, 65-146-481, Zabrana prodaje robe firme Bata po vašarima, 12. mart 1936. Iako je i u samom memorandumu Uprave Dunavske banovine bilo naznačeno da zabrana prodaje nije potpuno utemeljena u zakonskim propisima, ipak je zbog teške socijalne situacije sitnih zanatlija i trgovaca bilo preporučeno da se firmi Bata ne izdaju dozvole za prodaju svoje robe po različitim vašarima u ovoj banovini. 
pularne po manjim mjestima, bile su neki od glavnih izvora zarada putujućih trgovaca i sitnih zanatlija.

Povećanje intenziteta protesta i akcija protiv firme Bata u Jugoslaviji registrovalo je i čehoslovačko Poslanstvo u Beogradu, koje je pomno pratilo antiBatine akcije. Porast intenziteta tih protesta je objašnjavan velikom novčanom injekcijom koju je dobio „Centralni komitet akcionih odbora za zaštitu nacionalne kožarsko-prerađivačke radinosti u Kraljevini Jugoslaviji““ ${ }^{74}$ Ovo udruženje, sa sjedištem u Zagrebu, imalo je namjeru da koordiniše različite akcije protesta i bojkota protiv firme Bata i trudilo se da spriječi dalje širenje poslovanja firme. ${ }^{75}$ Osim toga, $\mathrm{u}$ tom razdoblju je donesena odluka o zabrani radionica za popravak obuće, za koju su smatrali da će „bistri i agilni direktor Borova, Maksimović, naći način da se prilagodi i radionice otvori pod izmijenjenom agendom i na novoj osnovi“. Ipak po povjerljivim informacijama koje je posjedovalo Poslanstvo, najveći problem je predstavljala činjenica da je predsjednik Ministarskog savjeta Nikola Uzunović pridobijen od strane anti-Batine koalicije i da planira da uvede kontingentizaciju proizvodnje obuće. Ovakva mjera je bila izravno usmjerena protiv dobro razvijajućeg poslovanja u Borovu, pa je iz tih razloga Poslanstvo u Beogradu urgentno o tome obavijestilo Tomu Maksimovića. ${ }^{76}$ Činjenicu da je Jugoslavija zabranila radionice za popravak obuće industrijskih preduzeća u svojoj argumentaciji koristila su i obućarska udruženja u samoj Čehoslovačkoj, koja su od svoje vlade zahtijevala uvođenje sličnih mjera. ${ }^{77}$ Protesti protiv firme Bata su stizali sa svih strana zemlje, pa su se zanatlije iz Skoplja žalile da ih konkurencija firme Bata dovodi do prosjačkog štapa. Navodili su, uz to, da Bata koristi nelegalnu praksu i zaobilazi član 168 Zakona o radnjama, koji je zabranjivao rasprodaje, pošto su oglašavali ,jeftine nedjelje“ u kojima su prodavali robu u bescjenje (po 9, 12, 15 i 19 dinara - što je bilo višestruko manje od uobičajenih tržišnih cijena). ${ }^{78}$ Građani su tokom takvih sedmica kupovali obuću za cijelu godinu, dok su obućari ostajali bez sredstava za egzistenciju. Osim zanatlija sa krajnjeg, nerazvijenog juga zemlje, i oni sa mnogo razvijenijeg sjevera, iz Dravske banovine takođe su protestovali protiv firme Bata i njene ekspanzije. ${ }^{79}$

Situaciju sa firmom Bata je pomno posmatralo i domaće Ministarstvo trgovine $\mathrm{i}$ industrije, koje je i u svojim internim memorandumima naglašavalo da sa trgovačko-političko-socijalnog stanovišta za cjelokupno društvo nije poželjno odobravati promjene pravila dioničkog društva Bata d. d. kojima bi ono moglo da proširi djelokrug svoje proizvodnje, pošto je to moglo da dovede do

\footnotetext{
${ }^{74}$ Udruženje je zvanično okupljalo male proizvođače i obućarske zanatlije, ali je čehoslovačko Poslanstvo u Beogradu smatralo da njihove akcije finansiraju veće domaće fabrike iz kožarske industrije.

${ }^{75}$ AJ, 65-702-1436, Peticija Centralnog komiteta akcionih odbora za zaštitu nacionalne kožarskoprerađivačke radinosti u Kraljevini Jugoslaviji, 20. mart 1936.

${ }^{76}$ AMZV, f. IV sekce, k. 1082, Akce protiv firme Bata v Borovu u Vukovaru, 12. septembar 1934.

${ }^{77}$ AMZV, f. IV sekce, k. 1082, Zrušeni továrních správkáren obuvi, 25. septembar 1934.

${ }^{78}$ AJ, 65-146-481, Firma Bata u Skoplju - nelojalna konkurencija, 2. maj 1934.

${ }^{79}$ AJ, 65-146-481, Interpelacij okrožni odbor obrtnih združenj v Novem mestu, 25. avgust 1934.
} 
novih socijalnih protesta. Takođe i svako povećanje kapitala, iako je poželjno sa makroekonomskog gledišta, moralo je biti vezano za poboljšanje postojeće proizvodnje i obrta već postojećih prodavnica, ali nije smelo biti upotrebljeno za otvaranje novih ili proširivanje postojećih industrijskih postrojenja i prodavnica. $^{80}$ Tragom pomenute politike neke od sreskih uprava su sredinom 1935. godine počele da kažnjavaju firmu Bata i njene poslovnice zbog prodaje gumenih opanaka. Kako su opanci bili osnovna obuća miliona seljaka, koji su činili većinu stanovništva u Jugoslaviji, prodaja opanaka je održavala u životu desetine hiljada zanatlija. Dolaskom Bate počela je proizvodnja gumenih opanaka na veliko, koji su istiskivali tradicionalne kožne opanke. Po tumačenju pojedinih sreskih nadleštava, dozvola za rad firme Bata, koja je glasila: „Da se tvrtka bavi tvorničkom proizvodnjom cipela, gumene obuće, gumenih đonova i potpetica“, odnosila se na proizvode obućarskog zanata po Zakonu o radnjama član 23, tačka 50, a nije važila za proizvode opančarskog zanata, koji su bili pod tačkom 52 istog člana tog zakona. Komplikovana jugoslovenska pravna struktura u kojoj su do usvajanja tog Zakona o radnjama za pojedine dijelove države važili drugačiji zakoni dovela je do nedoumica i do slučajeva kada su u pojedinim okruzima za prodaju gumenih opanaka naplaćivane kazne, a u drugima nisu. ${ }^{81}$

Protesti protiv Bate su svoj vrhunac doživjeli na prelomu 1935/36. godine, kada su u velikom broju mjesta održane razne akcije usmjerene protiv širenja firme, što je u krajnjoj liniji gotovo dovelo do usvajanja zakonske odredbe kojom bi bila usporena dalja ekspanzija firme. Te akcije su uključivale protestne povorke, demonstrativno zatvaranje sopstvenih radionica i radnji, slanje rezolucija u kojima je zahtijevano zatvaranje ili ograničavanje rada Borova, a ponekad i nasilne demonstracije koje su završavale razbijanjem izloga Batinih prodavnica. ${ }^{82}$ Tako je Zanatska komora u Sarajevu u martu 1936. izvještavala o učestalim napadima na Batine prodavnice nakon održanih protesta, koji su bili djelo očajnih pojedinaca. ${ }^{83} \mathrm{U}$ Vršcu je grupa od dvadesetak majstora i njihovih pomoćnika krajem oktobra 1935, nakon protesta ispred zgrade Opštine, kamenicama i cjepanicama porazbijala izloge prodavnice Bata u glavnoj gradskoj ulici. ${ }^{84}$ Pored nasilnih protesta, obućari su pribjegavali i kontraproduktivnim mjerama, poput zatvaranja sopstvenih radnji u Ljigu 10. februara $1936 .{ }^{85}$

\footnotetext{
${ }^{80}$ AJ, 65-146-481, Bata d. d. - promjena pravila društva, 29. juli 1935.

${ }^{81}$ AJ, 65-146-481, Firma Bata d. d. - proizvodnja opanaka, 9. juni 1935. Tako je u Bosni do tada važio zakon o radnjama iz 1910. godine koji nije razdvajao obućarsku i opančarsku struku.

${ }^{82}$ AMZV, f. IV sekce, k. 1082, Jugoslávie: Boj proti firme Bat’a - Anketa svolaná ministrem obchodu, 29. februar 1936.

${ }^{83}$ AJ, 65-702-1436, Dopis Zanatske komore u Sarajevu, 11. mart 1936.

${ }^{84}$ AJ, 65-146-481, Predstavka Udruženja zanatlija za grad Vršac, 10. decembar 1935. Policija je osim obućara za incident okrivila i poslovođu te prodavnice Đuru Medića, koji je po njima pridonio time što se izazivački šepurio ispred prodavnice kada je pored nje prolazila protestna kolona, a zatim i verbalno vrijeđao učesnike. Nakon toga su obućari Slavko Bavenski, Ivan Rešić i Rudolf Kin sa svojim pomoćnicima Živom Kosorom, Bogdanom Građanskim, Petrom Frisom i Đurom Rodićem kamenicama i cjepanicama razbili četiri izloga Batine prodavnice. Nekoliko policajaca koji su obezbjeđivali skup je tek nakon dolaska pojačanja uspjelo da obuzda nasilje i uhapsi počinioce.

${ }^{85}$ AJ, 65-702-1436, Zatvaranje radnji u Ljigu, 20. februar 1936.
} 
U politiku anti-Batinih protesta i peticija su se povremeno uključivali i antisemitski motivi. Tako je u pismu jednog trgovca iz Splita stajalo pitanje zbog čega se ometa rad firme Bata, koja je slovenskog porijekla, a ne ometa rad i ne protestuje protiv jevrejskih fabrika, poput Astre, i drugih neslovenskih preduzeća. Po tom trgovcu, ograničavanjem rada tvornice u Borovu, koja je najsavremenijim metodama proizvodnje snabdijevala stanovništvo jeftinom i kvalitetnom obućom, samo bi se pomogle, ,jevrejsko-mađarsko-njemačka izrabljivačka tvornica Astra i druge anti-nacionalne fabrike" ${ }^{86}$ Pojavljivali su se i drugi elementi, pa je tako trgovac M. Madunić iz Bosanskog Broda poštom slao Batine cipele $u$ Ministarstvo trgovine $\mathrm{i}$ industrije, u kojima je navodno, umjesto kože, dio đona bio napravljen od kartona ${ }^{87}$ Proizvođači obuće i kože poput fabrike Petra Arambašića iz Beograda i Andrije Jakila iz Karlovca takođe su ukazivali na praksu usvajanja anti-Batinih zakona u Švajcarskoj i Francuskoj, koji su imali za cilj zaustavljanje ekspanzije ove kompanije, i tražili su uvođenje sličnih mjera u Kraljevini Jugoslaviji. ${ }^{88}$

Nasuprot organizovanom otporu zanatlija, $u$ tadašnjem jugoslovenskom društvu su se mogli čuti i glasovi podrške ekspanziji firme Bata na domaćem tržištu. U tom smislu naročito su se isticali seljaci i njihova udruženja. Po formulaciji dopisa Pete srpske zemljoradničke zadruge iz Vršca, u uslovima sveopšte skupoće i nemogućnosti da za svoje poljoprivredne proizvode dobiju adekvatnu novčanu vrijednost, niske cene Batinih proizvoda su uveliko olakšavale život seljaka. Iz tih razloga traženo je da se ne usliše molbe obućara o zatvaranju Batinih prodavnica i da im se, nasuprot tome, omogući nesmetano poslovanje. ${ }^{89}$ Savez srpskih zemljoradničkih zadruga koji je okupljao 1.200 zadruga i nekoliko stotina hiljada članova takođe je protestovao zbog ograničenja koja su namjeravana biti nametnuta po pitanju proizvodnje gumenih opanaka. ${ }^{90}$ Kampanja koja je vođena protiv gumenih opanaka kao nezdravog proizvoda direktno je pogađala brojne seljake kojima je ova jeftina obuća bila neophodna u njihovom životu i radu.

Kako je Ministarstvo trgovine i industrije bilo zatrpavano rezolucijama, a protesti nisu jenjavali, ministar Milan Vrbanić je sazvao sastanak u Beogradu, na kojem su u dva dana, 27-28. februara 1936, bili predstavljeni stavovi svih zainteresovanih strana. Na sastanku su učestvovali predstavnici svih privrednih komora u zemlji, kao i predstavnici Zemaljskog saveza industrijalaca i firme Bata Borovo. Svoje izaslanike poslali su i Akcioni odbor za zaštitu kožarske proizvodnje, Savez obućarskih majstora, Ministarstvo socijalnog rada, ministarstva vojske, zemljoradnje i finansija, kao i Glavni savez srpskih zemljoradničkih društava. ${ }^{91}$ Ministar Vrbanić je na otvaranju sastanka proglasio da se na njemu ne rješava boj obućara sa Batom, već sukob zanatlijske maloproizvodnje i industrije pomognute moćnim

\footnotetext{
${ }^{86}$ AJ, 65-702-1436, Akcija protiv Bate, 27. februar 1936.

${ }^{87}$ AJ, 65-702-1436, Kožne cipele Bata, 6. maj 1936.

${ }^{88}$ AJ, 65-702-1436, Dopis And. Jakila, 28. april 1936.

${ }^{89}$ AJ, 65-702-1436, Peta srpska zemljoradnička zadruga Vršac, 20. februar 1936.

${ }^{90}$ AJ, 65-702-1436, Savez srpskih zemljoradničkih zadruga, 21. februar 1936.

${ }^{91}$ AMZV, f. IV sekce, kart. 1082, Jugoslávie: Boj proti firme Bata - Anketa svolaná ministrem obchodu, 29. februar 1936.
} 
kapitalom. Na skupu su se tokom dva dana mogle čuti uobičajene optužbe na račun firme Bata, to jest da je hiperracionalizovala proizvodnju i otuđila radnike od sredstava za proizvodnju, povećala nezaposlenost i ugrozila opstanak obućara i članova njihovih porodica. Iznošene su i optužbe o zdravstvenoj štetnosti gumenih opanaka, kao i to da firma Bata ne plaća poreze i ostale doprinose u skladu sa time da je najveća fabrika za proizvodnju obuće i vlasnik preko 400 prodavnica u zemlji. Kao zagovornik rada Bate je na tom sastanku istupio Velimir Bajkić ${ }^{92}$ koji je, kao ugledni ekonomista, zastupao tezu o koristi koju je ova firma donijela cjelokupnoj industrijalizaciji i napretku zemlje. Njegov osnovni argument je bio zasnovan na tvrdnji da bi bez Bate snabdjevenost stanovništva obućom bila još gora nego što jeste, jer je i onako bila jedna od najlošijih u Evropi. ${ }^{93}$ Osim njega, na sastanku je istupio i Toma Maksimović koji je, po riječima iz Poslanstva u Beogradu, ,sa religijskim zanosom branio ideju i poslovanje firme Bata, i isticao svoj ponos na ideologiju batizma koja je vladala u Borovu“. ${ }^{94}$ Voja Đorđević, predsjednik Glavnog saveza srpskih zemljoradničkih udruženja, istakao je da zemljoradnike ovaj spor ne zanima i da je jedini kriterijum za potrošača cijena, ${ }^{95}$ odnosno da bi bez Batinih gumenih opanaka više od polovine srpskih seljaka okolo hodalo boso. ${ }^{96}$ Navedeni argumenti u Batinu korist ipak nisu otupili oštricu ranije izrečenih optužbi, pa je poslije nekoliko mjeseci Ministarski savjet Kraljevine Jugoslavije počeo sa radom na donošenju zakonske uredbe o trogodišnjem moratoriju na podizanje novih ili proširivanje postojećih industrijskih pogona za proizvodnju obuće. Pokrenuta je i ministarska konferencija, na kojoj su usaglašavani stavovi, što se može vidjeti iz prepiske u koju su bila uključena najvažnija ministarstva, poput ministarstava trgovine $\mathrm{i}$ industrije, unutrašnjih poslova, finansija, socijalne politike i narodnog zdravlja, kao i Ministarstvo pošte, telegrafa i telefona. ${ }^{97}$ Nakon konsul-

\footnotetext{
92 Velimir Bajkić (Veliko Gradište, 20. februar 1875 - Buenos Ajres, 17. februar 1952), istaknuti srpski i jugoslovenski ekonomista prve polovine 20. vijeka. Nakon oba svjetska rata u Jugoslaviji je radio kao ekspert na pitanju valutne reforme i zamjene starog novca. U međuratnom razdoblju kao i tokom Drugog svjetskog rata imao je važne poslovne veze sa firmom Bata. Bio je u upravnom odborima Bate do 1941, a od 1941. do 1944. obavljao je dužnost direktora firme Bata d. d. u Srbiji. Tokom 1929. pokrenuo je časopis Narodno blagostanje, posvećen aktuelnim ekonomskim pitanjima, koji je svojim sadržajem bio veoma naklonjen politici i ekspanziji firme Bata na jugoslovenskom tržištu. Osim toga, vodio je predstavništva firmi Tomas Votson, kao i jugoslovensku filijalu firme IBM, a bio je i u upravnim odborima firmi Shell i Standard Oil u Jugoslaviji. Nakon rata i uspostave novog režima u Jugoslaviji radio je u Ministarstvu finansija, da bi 1948. godine emigrirao u Argentinu gdje je i umro. Više o Velimiru Bajkiću u: Vesna Matić, Finansije srpske (Beograd: Udruženje banaka Srbije, 2014); Velimir Bajkić, Izabrani spisi (Beograd: Službeni glasnik, 2009).

${ }^{93}$ Statistički gledano, jedan stanovnik je godišnje kupovao $1 / 2$ para cipela.

${ }^{94}$ AMZV, f. IV sekce, kart. 1082, Jugoslávie: Boj proti firme Bat'a - Anketa svolaná ministrem obchodu, 29. februar 1936.

95 Prosječna cijena jednog para obuće u Jugoslaviji prije podizanja fabrike u Borovu bila je oko 200 dinara. Početkom 1936. cijena jednog para obuće iz Batine proizvodnje kretala se između 49 i 79 dinara. Borovo, 1. januar 1936.

${ }^{96}$ AMZV, f. IV sekce, kart. 1082, Jugoslávie: Boj proti firme Bat’a - Anketa svolaná ministrem obchodu, 29. februar 1936.

${ }^{97}$ AJ, 65-702-1436, Prepiska u vezi Uredbe o proizvodnji, opravci i prodaji obuće Ministarskog saveta Kraljevine Jugoslavije, 6. juli 1936.
} 
tacija i pregovora, koji su trajali nekoliko mjeseci, u julu 1936. pripremljena je zakonska uredba, slična propisima koji su ranije doneseni u Švajcarskoj i Francuskoj. Iako su se sva zainteresovana ministarstva složila oko teksta ove uredbe, ona nije nikada provedena u praksi, to jest nije došlo do njenog konačnog usvajanja i objavljivanja u Službenim novinama. Razlog za odstupanje od već donesene odluke sa ove vremenske distance nije moguće otkriti, ali indikativna je šutnja inače vrlo dobro obavještenog čehoslovačkog Poslanstva u Beogradu o ovom pitanju. ${ }^{98}$ Sama odluka je stavljena ad acta tek u februaru 1940. godine.

Pripremljena i neobjavljena uredba o proizvodnji, opravci i prodaji obuće iz jula $1936:{ }^{99}$

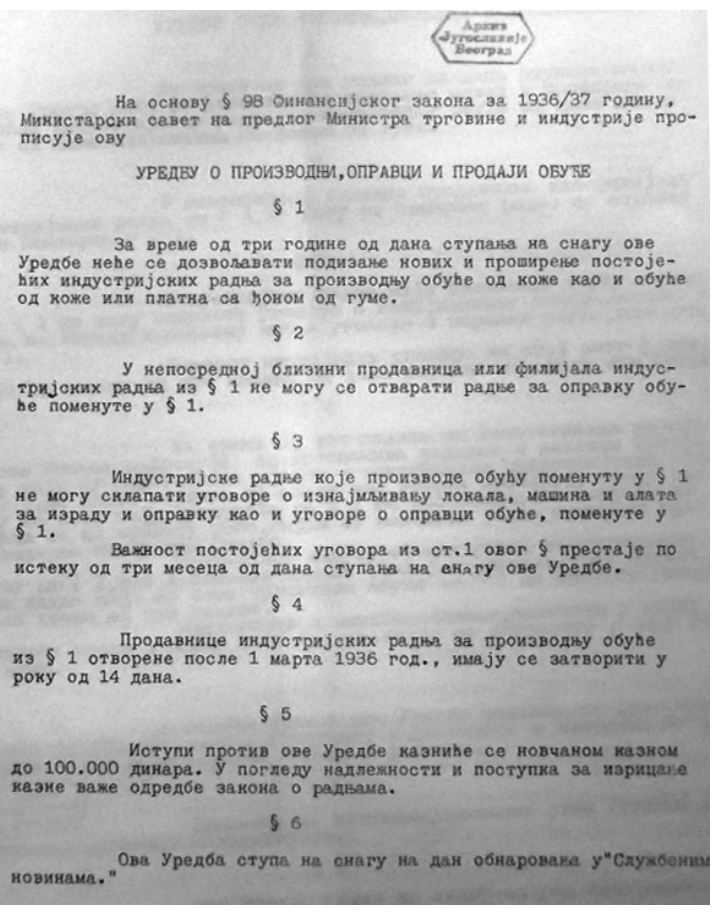

Pomenuta odluka je trebalo da spriječi uništavanje individualne proizvodnje $\mathrm{i}$ omogući opstanak zanatlija što je, po mišljenju odgovornih ljudi u Vladi Kraljevine, bilo značajnije za fiskalne interese države. Uz to, trebalo je da sa socijalne strane spriječi proteste zanatlija, kao i njihovu proleterizaciju i prelazak u masu nezaposlenih koja je ionako bila velika. Takođe, trogodišnja zabrana otvaranja novih prodavnica kao i zabrana otvaranja novih i proširenja postojećih industrijskih postrojenja za proizvodnju obuće trebalo je da doprinese uspješnijem prilagođavanju domaće industrije i

98 Čehoslovačko Poslanstvo u Beogradu je još od uspostavljanja diplomatskih odnosa između dve novostvorene države imalo jednu od najznačajnijih pozicija u beogradskom diplomatskom koru. Zahvaljujući predanom radu prvih poslanika, Antonjina Kaline (Antonín Kalina) i Jana Šebe (Jan Šeba), uspostavljene su duboke veze sa političkom elitom Kraljevine SHS, kasnije Jugoslavije. Saveznički odnosi kroz Malu antantu i intenzivni ekonomski odnosi doprinosili su tome da Poslanstvo uvijek bude dobro obaviješteno o dešavanjima u Beogradu. Jan Šeba je tokom svog dugog službovanja (1923-1930) uspostavio srdačne odnose sa više predsjednika vlada, kao i sa samim kraljem Aleksandrom I Karađorđevićem. Iako njegovi nasljednici na tom položaju, Robert Flider (Robert Flieder) koji je obavljao dužnost poslanika u periodu kada je Bata osnivao fabriku u Jugoslaviji, Pavel Verner (Pavel Werner), Vaclav Girsa (Václav Girsa) i Jaroslav Lipa (Jaroslav Lípa) nisu imali takav uticaj kao njihovi prethodnici, veze iz prethodnog perioda su i dalje bile duboke i razvijene, što je dovodilo do veoma dobre obaviještenosti o situaciji u zemlji. Više o Janu Šebi i njegovom radu u Beogradu, kao i o diplomatskima aktivnostima u Kraljevini SHS/Jugoslaviji u: Jindrich Dejmek, Jan Šeba: Paměti legionář a diplomata (Praha: AV ČR, 2016).

${ }^{99}$ AJ, 65-702-1436, Uredba o proizvodnji, opravci i prodaji obuće Ministarskog saveta Kraljevine Jugoslavije. 
zanatlija na Batinu konkurenciju. ${ }^{100}$ Do sredine 1936. godine, kada je vođena navedena debata i planirane mjere protiv dalje ekspanzije firme, Bata je već, po podacima nadležnog Ministarstva, otvorila 443 radnje, uz planirano otvaranje novih, a njihovo rasprostiranje pokazuje naredna tabela:

\begin{tabular}{|l|c|}
\hline Broj stanovnika & Broj prodavnica \\
\hline Mjesta sa manje od 500 stanovnika & 3 \\
\hline Od 500 do 1.000 stanovnika & 16 \\
\hline Od 1.000 do 1.500 & 35 \\
\hline Od 1.500 do 2.000 & 45 \\
\hline Od 2.000 do 3.000 & 58 \\
\hline Od 3.000 do 4.000 & 66 \\
\hline Od 4.000 do 5.000 & 50 \\
\hline Od 5.000 do 7.500 & 67 \\
\hline Od 7.500 do 10.000 & 34 \\
\hline Od 10.000 do 15.000 & 35 \\
\hline Od 15.000 do 20.000 & 11 \\
\hline Od 20.000 do 25.000 & 5 \\
\hline Od 25.000 do 30.000 & 1 \\
\hline Od 30.000 do 40.000 & 9 \\
\hline Od 40.000 do 50.000 & 1 \\
\hline Od 50.000 do 100.000 & 4 \\
\hline Preko 100.000 & 3 \\
\hline Ukupno & 443 \\
\hline
\end{tabular}

Prodavnice Bata u Jugoslaviji otvorene do polovine 1936. godine $\mathrm{e}^{101}$

Pregled prodavnica daje jasnu sliku o nastojanjima firme Bata da svoja prodajna mjesta otvori i po manjim mjestima, što je išlo na štetu zanatlija, koje se nisu mogli boriti protiv takve konkurencije. Prisjetimo se da je istovremeno firma Bata i dalje zaobilazila zabranu o radionicama za popravku obuće, to jest imala je ugovore sa obućarima koji su to radili umjesto nje. U 1936. godini ovih obućara je već bilo preko 200 .

${ }^{100}$ AJ, 65-702-1436, Motivacija za donošenje uredbe o proizvodnji, opravci i prodaji obuće, 21. juni 1936. Javnost je pad broja obućara pripisivala najviše uticaju i djelovanju firme Bata, koja je prvo preko uvoza jeftinije obuće iz Čehoslovačke, a kasnije i preko pokretanja sopstvene fabrike u Borovu, doprinijela krahu domaće obućarske industrije. Ipak, ono što su protivnici firme Bata morali da priznaju jeste činjenica da je nakon početka rada tvornice u Borovu došlo kako do smanjenja uvoza obuće, tako i do smanjenja uvoza sirovina i poluprerađevina iz inostranstva, pošto je samo tokom 1934. firma Bata otkupila u Jugoslaviji sirovine i poluprerađevine u iznosu od 63,5 miliona dinara.

${ }^{101}$ AJ, 65-702-1436, Motivacija za donošenje uredbe o proizvodnji, opravci i prodaji obuće. 


\begin{tabular}{|l|r|}
\hline \multicolumn{1}{|c|}{ Vrsta ugovornog odnosa } & \multicolumn{1}{c|}{ Broj obućara } \\
\hline $\begin{array}{l}\text { Obućarski majstori kojima je firma iznajmila } \\
\text { lokal i mašine po ugovoru o popravljanju obuće }\end{array}$ & 58 \\
\hline Obućari kojima je iznajmljen uređaj & 29 \\
\hline Obućari kojima je iznajmljen lokal & 120 \\
\hline $\begin{array}{l}\text { Obućari koji popravljaju Batinu obuću u sop- } \\
\text { stvenom lokalu sa sopstvenim uređajima }\end{array}$ & 209 \\
\hline Ukupno & \\
\hline Obućari sa kojima je firma Bata sklopila ugovor o popravci obuće & \\
\hline
\end{tabular}

Oštrica anti-Batinih protesta je otupila nakon 1936, ali su se, iako se firma potpuno etablirala na jugoslovenskom tržištu i osim najveće prodajne mreže raspolagala i sa najvećom, dominantnom proizvodnjom, i dalje pojavljivali sporadični pokušaji obućarske zajednice da se odupre njenoj tržišnoj ekspanziji. Tako je Glavni zanatlijski savez Kraljevine Jugoslavije 1938. godine poslao opširnu peticiju i analizu predsjedniku Vlade Milanu Stojadinoviću kojom je dokazivana štetnost uticaja Bate na domaću privredu. ${ }^{103}$ Ipak, ovakve peticije i apeli nisu imali dejstva, kako na samog Milana Stojadinovića, tako i na Ministarstvo trgovine i industrije, jer ono nije aktiviralo povučenu uredbu iz 1936. godine.

\section{Zaključna razmatranja i preporuke za buduća istraživanja}

Poslovne aktivnosti firme Bata u Kraljevini SHS/Jugoslaviji predstavljaju plastičan primjer za razumijevanje društveno-istorijskih protivrječnosti vezanih za procese (anti)industrijalizacije. U tom smislu, one mogu biti tumačene u globalnom i lokalnom kontekstu. U globalnom kontekstu, firma Bata je $\mathrm{u}$ samo nekoliko decenija, od skromnih početaka u provincijskom dijelu AustroUgarske, postala najveći svjetski proizvođač i izvoznik obuće. Taj poslovni uspjeh nije počivao na spletu povoljnih političko-ekonomskih okolnosti, već na ličnoj preduzetničkoj inicijativi i usvajanju naprednih oblika organizacije industrijske proizvodnje. Drugim riječima, vlasničko-upravljačke strukture firme Bata su išle u korak sa „duhom vremena“, to jest svoje poslovne aktivnosti su prevashodno zasnivale na principima instrumentalne racionalnosti. Po tom osnovu firma Bata je u međuratnom periodu širom Evrope doživljavana kao simbol modernizacije, ali taj simbolizam je imao drugačiju konotaciju u industrijski razvijenoj Zapadnoj Evropi u odnosu na pretežno agrarnu Kraljevinu SHS/Jugoslaviju.

102 AJ, 65-702-1436, Motivacija za donošenje uredbe o proizvodnji, opravci i prodaji obuće. Za svaku vrstu preuzimanja popravke firma je imala poseban obrazac, koji je onemogućavao samostalnost obućara. Oni su bili obavezni da primaju Batinu obuću tako da su, iako pravno gledano samostalne, ove radnje bile samo radionice za popravku obuće za firmu Bata.

103 AJ, 65-702-1436, Dopis Predsjedniku Kraljevske Vlade i Ministru inostranih poslova, dr. Milanu Stojadinoviću, 1. oktobar 1938. 
U Zapadnoj Evropi poslovne aktivnosti firme Bata prvenstveno su doživljavane kao simbol specifičnog modela ekonomske modernizacije - amerikanizacije, pa u tom kontekstu i anti-Batini protesti nisu predstavljali otpor prema industrijskom razvoju samom po sebi, već prema poslovnoj filozofiji i praksi koje je zastupala ta kompanija. Stoga ne treba da iznenađuje ,neprirodni savez" između glavnih aktera tih protesta - radništva i industrijalaca pomenutih zemalja. Uzimajući u obzir tadašnju konstelaciju klasnih odnosa, to jest da su pomenuti akteri bili i nosioci političke moći, njihov zajednički angažman (barem privremeno zasnovan na principu ,neprijatelj mog neprijatelja je moj prijatelj ${ }^{\text {‘) }}$ ) dao je vrlo opipljive rezultate po pitanju ograničavanja Batine poslovne ekspanzije na tržišta zapadnoevropskih zemalja.

Nasuprot tome, u Kraljevini SHS/Jugoslaviji firma Bata nije isključivo doživljavana kao simbol ekonomske modernizacije, već i kao otvorena prijetnja za tradicionalni način života određenih društvenih slojeva - odnosno ne samo njihov ekonomski i politički status, već i (pot)kulturne obrasce. U tom smislu, otpor domaćih obućara je imao izražene antiindustrijske/antimodernizacijske karakteristike. Međutim, i pored relativne brojnosti, pripadnici pomenutog sloja domaćih zanatlija nikada nisu bili nosioci političke moći, niti su bili u prilici da pronađu (van)klasne saveznike koji bi im pomogli u njihovim aktivnostima usmjerenim protiv Bate (to jest usljed nerazvijenosti kožarske industrije u Kraljevini SHS/Jugoslaviji nisu mogli računati na radništvo i industrijalce sa kojima bi dijelili zajedničke interese po tom pitanju). Nasuprot tome, protiv njih su bili određeni društveni slojevi koji su imali dijametralno različite interese po tom pitanju - u prvom redu seljaštvo (zbog pristupa jeftinoj obući). Uzimajući u obzir brojnost i političku snagu seljaštva u tadašnjoj jugoslovenskoj državi, odnosno njihov aktivan uticaj na izražena antiindustrijska kretanja u jugoslovenskom društvu, očigledno je da „Batin gumeni opanak“ predstavlja i više nego očigledan primjer situacije u kojoj određena industrijska grana/proizvod podstiče jednu, a gasi drugu tradicionalnu ekonomiju/način života. Iz te perspektive, posljedice anti-Batinih protesta organizovanih na teritoriji Kraljevine SHS/Jugoslavije, iako se po efikasnosti ne mogu porediti sa sličnim društvenim kretanjima u Zapadnoj Evropi, ipak dobijaju na težini.

Svjesni smo da je izviđajni karakter našeg istraživanja i pored težnje ka interdisciplinarnom pristupu (istoriografsko-sociološkom) u velikoj mjeri uslovio da naša razmatranja pretežno ograničimo na ekonomsku dimenziju proučavanih društveno-istorijskih procesa. U tom kontekstu, nadamo se da će prezentovani istraživački rezultati predstavljati dobar osnov za nova istraživanja na ovu temu. S obzirom na dostupnu arhivsku građu smatramo da bi takvi naučni poduhvati, pored veće pažnje posvećene političkim i/ili kulturnim aspektima predstavljenih društvenih procesa, navedenoj problematici mogli da pristupe i iz drugačije istraživačke perspektive - na primjer, proučavanjem dostupnih auto/biografskih izvora o akterima predstavljenih društveno-istorijskih dešavanja. 


\section{REFERENCE}

- Asemoglu Daron, i Džejms A. Robinson. Zašto narodi propadaju: Poreklo moći, prosperiteta i siromaštva. Beograd: Clio, 2014.

- Balaban, Milan. Podnikáni firmy Bata v Jugoslávii. Zlín: Univerzita Tomáše Bati, 2018.

- Balaban, Milan. "Yugoslav-Czechoslovak Economic Relations between 1918 and 1938 year". Doktorská disertace, Filozofická fakulta Masarykové univerzity, Brno, 2016.

- Balaban, Milan. "General overview of Yugoslav-Czechoslovak economic and trade relations for period between 1918 and 1938”. Slovanský přehled, 102, br. 3, (2016), 503-612.

- Bajkić, Velimir. Izabrani spisi. Beograd: Službeni glasnik, 2009.

- Cekota, Antonín. Geniální podnikatel Tomáś Bata. Toronto: Sixty-Eight Publishers, 1981.

- Čalić, Mari-Žanin. Socijalna istorija Srbije 1815-1941. Beograd: Clio, 2004.

- Dejmek, Jindřich. Jan Šeba: Paméti legionáře a diplomata. Praha: AV ČR, 2016.

- Dimitrijević, Sergije. Karakteristike industrije i rudarstva bivše Jugoslavije. Beograd: Biblioteka Društva ekonomista Srbije, 1949.

- Đurović, Smiljana. Državna intervencija u industriji Jugoslavije (1918-1941). Beograd: Institut za savremenu istoriju, 1986.

- Gatti, Alain. Chaussures les hommes qui vont pieds nus: Bata-Hellocourt, 19312001: enquete sur la memoire industrielle et sociale. Metz: Serpenoise, 2004.

- Hodáč, X. František. Tomáš Bata: Život a práce hospodářského buditele. Zlín: Univerzita Tomáše Bati, 2015.

- Hrelja Kemal, i Martin Kaminski. Borovo. Jugoslovenski kombinat gume i obuće. Slavonski Brod: Historijski institut Slavonije, 1971.

- Kubů, Eduard. „Die Bata-Gefahr“: Anti-bat'ovská propaganda a bojkotové akce v Německu na přelomu 20. a 30. let 20. stoleti'“. U: Pocta Janu Janákovi: předsedovi Matice moravské, profesoru Masarykovy univerzity věnuji k sedmdesátinám jeho přátelé a žáci. Ed. Bronislav Chocholáč i Jiř́i Malíŕ, 527539. Brno: Matice moravská, 2002.

- Kukoleča, M. Stevan. Industrija Jugoslavije 1918-1938. Beograd: Balkanska štampa a. d., 1941.

- Jemelka Martin, i Ondřej Ševeček. Tovární města Batova koncernu: Evropská kapitola globálni expanze. Praha: Academia, 2016.

- Lehár, Bohumil. Dějiny Batova koncernu. Praha: SNPL, 1960.

- Matić, Vesna. Finansije srpske. Beograd: Udruženje banaka Srbije, 2014.

- Pagáć, Jaroslav. Tomáš Bata a 30 let jeho podnikatelské práce. Praha: Sfinx, 1926.

- Petranović, Branko. Istorija Jugoslavije 1918-1988, Knjiga prva, Kraljevina Jugoslavija. Beograd: Nolit, 1988. 
- Philipp, Rudolph. Der unbekannte Diktator Thomas Bata. Wien - Berlin: Agis - Verlag, 1928.

- Pokluda, Zdeněk. Člověk a práce: z ekonomických principů a vizí Tomáše Bati = Man and Work: The Vision and Principles of Economics of Tomas Bata. Zlín: Nadace Tomáše Bati, 2015.

- Pokluda, Zdeněk. Ze Zlína do světa - přiběh Tomáše Bati = From Zlin into the World - The Story of Tomas Bata. Zlín: Nadace Tomáše Bati, 2015.

- Schib, Karl. Geschichte des Dorfes Möhlin. Erschienen Thayngen: Augustin, 1959.

- Živić Dražen, i dr. Bata-Borovo (1931.-2016.). Povijesno naslijeđe i perspektive. Zagreb - Vukovar: Institut društvenih znanosti Ivo Pilar, 2019.

MILAN BALABAN, PhD, Research Associate

Tomas Bata University in Zlín, Bata Information Center

Zlín, The Czech Republic

balaban@utb.cz

DALIBOR SAVIĆ, PhD, Assistant Professor

University of Banja Luka, Faculty of Political Science

Banja Luka, Republic of Srpska, Bosnia and Herzegovina

dalibor.savic@fpn.unibl.org

JAN HERMAN, Mgr, Research Assistant

Tomas Bata University in Zlín, Bata Information Center

Zlín, The Czech Republic

herman@utb.cz

\author{
PROTESTS AGAINST THE BATA COMPANY: \\ CONTRIBUTION TO THE STUDY OF ANTI-INDUSTRIAL \\ PROCESSES IN THE KINGDOM OF SERBS, CROATS \\ AND SLOVENES/YUGOSLAVIA
}

\begin{abstract}
Summary
The paper presents an analysis of the anti-industrial processes in the Kingdom of Serbs, Croats and Slovenes, later the Kingdom of Yugoslavia. In this context, special attention was paid to the protests against the Bata Company, which by its arrival suppressed domestic industrial and artisan production in the leather industry, i.e. deepened the unfavorable social position of the population, existentially dependent on domestic footwear production. The Bata Company in Yugoslavia was founded in 1920 and until the end of the decade the retail network grew, but there was still no production, as the footwear and accessories were imported from Czechoslovakia. After the establishment of the
\end{abstract}


factory in Borovo in 1931, Bata became the dominant shoe producer in the entire country and covered almost 90 per cent of domestic production and sales. However, during its expansion, the Company was exposed to growing protests from domestic producers and small shoemakers. Those protests lasted almost a decade, peaking at the turn of $1935 / 1936$, by organizing mass demonstrations, which occasionally grew into violent incidents. These protests caused the adoption of several measures by the Yugoslav authorities, which limited the business of the company but did not adopt legislation that would take the form of a law, the so-called Lex Bata, which were adopted in Switzerland and France. After that peak, the protests slowly subsided, so that at the end of the decade, Bata completely took over the market of the Kingdom of Yugoslavia.

KEYWORDS: Bata Company, Yugoslavia, Czechoslovakia, Interwar Period, Anti-Industrial Protests, Footwear Industry, Craftsmen 